\title{
Editorial position on publishing articles on human organ transplantation
}

\begin{abstract}
The practice of transplanting organs from executed prisoners in China appears to be widespread. We vigorously condemn this practice and, effective immediately, will not consider manuscripts on human organ transplantation for publication unless appropriate non-coerced consent of the donor is provided and substantiated.
\end{abstract}

Organ transplantation in China has expanded rapidly over the past 20 years, particularly liver, kidney, and heart transplantation $(1,2)$. During this period of time, transplantation, once relatively uncommon in China, has begun to approach rates seen in other developed nations. It is undeniable that many residents of China have benefited from transplants of kidneys, livers, and other organs and tissues. Furthermore, the demand for transplants is far from satisfied, with the Chinese government reporting more than a million people in China needing a transplant every year $(3,4)$. Thus, as in the United States, and indeed every country, demand for organs far exceeds supply.

This disparity in the supply of organs is a particular problem in China, where rapid expansion of the capacity to perform transplants has not been accompanied by the development of a system for recovering organs from those who die in hospitals while on life support, as is international practice. There is almost no systematic recovery of voluntarily donated cadaver organs. No regional or national system exists for soliciting consent to donate organs in advance from those who die or their relatives after death $(5,6)$. Unfortunately, the evidence is clear that some physicians in China, in an effort to perform more transplants, are engaged in a practice that violates basic standards of medical ethics and human rights, namely the use of organs from executed prisoners (2-7).

Moreover, travel to China to secure organ transplants has not lessened. "Transplant tourists" find their way to China, frustrated by the long waiting times in their own countries, attracted by a competitive price, and seduced by a guarantee of a transplant. The only way to guarantee transplant of a liver or heart during the relatively short time period that a transplant tourist is in China is to quickly obtain the requisite medical information from prospective recipients, find matches among them, and then execute a person who is a suitable match $(7,8)$.

Using organs from executed prisoners violates basic human rights. It violates core ethical precepts of transplant medicine and medical ethics (9-11). Worse still, some of those who are killed may be prisoners whose "crimes" involve no more than holding certain political or spiritual beliefs.

There have been commendable efforts to protest the use of executed prisoners as organ donors. But presentations about transplantation in China continue to be made at international conferences, and publications about the experience of human transplantation in China appear in peer-reviewed journals (12).

The current and incoming editors of the JCI have decided to codify their opposition to the killing of prisoners to obtain organs for transplant by no longer considering for publication any submissions pertaining to or containing information about human organ transplantation in China unless there is an attestation that the organ sources are not executed prisoners. The prevalence of this practice in China is the raison d'être for our scrutiny of articles originating from there. However, we do not mean to single out that country alone - this policy will extend to any nation shown to be killing prisoners for their organs.

Open and free communication is a core value of science and medicine. There are many Chinese doctors and scientists who find the execution of prisoners morally abhorrent. We applaud their sentiments, support them fully, and do not wish to punish them with collective guilt. But the international biomedical community, including especially journal editors and editorial boards, must not be complicit with the practice of killing on demand to obtain organs from executed prisoners. We are not naive. We recognize that a boycott by this journal and its peers is unlikely, by itself, to bring an end to this practice. But we do hope that our actions will bring attention to this outrage and, in doing so, encourage China to develop policy options for obtaining organs consistent with international standards, conventions, and ethics.

\section{Arthur L. Caplan, Senior Editor}

\section{Howard A. Rockman, Incoming Editor in Chief}

\section{Laurence A. Turka, Editor in Chief}

1. China Liver Transplant Registry. Web site. https:// www.cltr.org/en/transplantcenters.jsp. Accessed October 29, 2011.

2. Doctors transplant organs taken from executed prisoners. The China Post web site. http://www.chinapost. com.tw/taiwan/local/taipei/2011/03/06/293573/ Doctors-transplant.htm. Updated March 6, 2011. Accessed November 17, 2011.

3. Malone A. China's hi-tech 'death van' where criminals are executed and then their organs are sold on black market. Mail Online web site. http://www. dailymail.co.uk/news/article-1165416/Chinas-hitech-death-van-criminals-executed-organs-soldblack-market.html. Updated March 27, 2009. Accessed November 17, 2011.

4. Foster P. China admits organs removed from prisoners for transplants. The Telegraph web site. http://www.telegraph.co.uk/news/worldnews/asia/ china/6094228/China-admits-organs-removedfrom-prisoners-for-transplants.html. Updated August 26, 2009. Accessed November 17, 2011.

5 . Wang M, Wang X. Organ donation by capital prisoners in China. J Med Philos. 2010;35(2):197-212.

6. Yu X. Cultural taboos and corruption. Newschina. 2011:17-19.

7. Danovitch GM, Shapiro ME, Lavee J. The use of executed prisoners as a source of organ transplants in China must stop. Am J Transplant. 2011; 11(3):426-428.

8. Matas D, Kilgour D. Bloody Harvest: Organ Harvesting of Falun Gong Practitioners in China. Woodstock, Ontario, Canada: Seraphim Editions; 2009.

9. Caplan AL, Dominguez-Gil B, Matesanz R, Prior C. Trafficking In Organs, Tissues And Cells And Trafficking In Human Beings For The Purpose Of The Removal OfOrgans. Joint Council of Europe/United Nations Study, 2009. Strasbourg, France: Directorate General of Human Rights and Legal Affairs Council of Europe; 2009.

10. WHO. Draft guiding principles on human organ transplantation. WHO web site. http://www.who.int/ ethics/topics/transplantation_guiding_principles/ en/index1.html. Accessed August 7, 2011.

11. WMA. WMA council resolution on organ donation in China. World Medical Association web site. http:// www.wma.net/en/30publications/10policies/ 30council/cr_5/.Accessed August 7, 2011.

12. Shi BY, Chen LP. Regulation of organ transplantation in China: difficult exploration and slow advance. JAMA. 2011;306(4):434-435. 